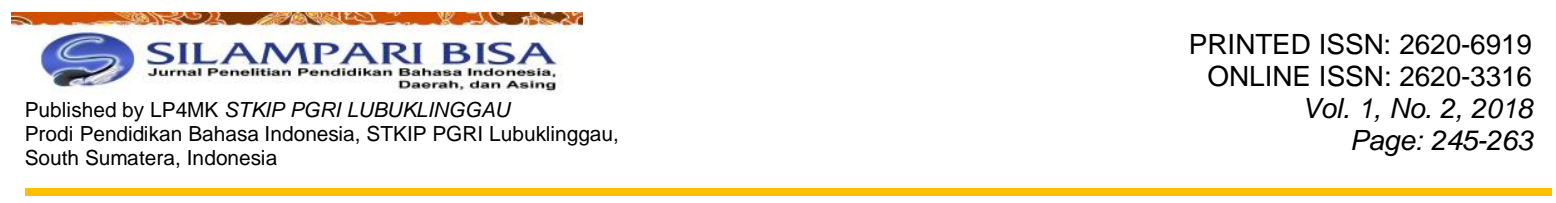

\title{
KOMUNIKASI SASTRA PADA PUISI SELAMAT TAHUN BARU KAWAN KARYA MUSTOFA BISRI
}

\author{
Andika Hendra Mustaqim \\ Program Studi Bahasa Inggris \\ Fakultas Komunikasi dan Bahasa, Universitas Bina Sarana Informatika (UBSI) \\ JIn. Salemba Tengah No. 45 Jakarta Pusat, Indonesia \\ Email: andika.ahq@bsi.ac.id
}

Submitted: $31-$ October-2018

Accepted : 31-December-2018
Published: 31-December-2018

DOI: $10.31540 /$ silamparibisa.v1i2.139

URL: https://doi.org/10.31540/silamparibisa.v1i2.139

\begin{abstract}
Abstrak
Tujuan penelitian ini adalah untuk memberikan pemahaman tentang komunikasi sastra pada puisi Selamat Tahun Baru Kawan karya KH Mustofa Bisri (Gus Mus) dengan fokus membongkar sistem bahasa dan sistem sosio-budaya. Pendekaan penelitian ini adalah kualitatif dan menggunakan metode analisis isi. Teknik pengumpulan data menggunakan teknik dokumentasi. Teknik analisis data dimulai dari menyusun ringkasan abstraksi berupa korpus, eksplikasi, dan penataan struktur. Hasil penelitian ini menunjukkan bahwa sistem bahasa pada puisi karya Gus Mus tersebut memunculkan makna yang bisa ditarik dari segi denotatif dan konotatif. Kemudian, permainan diksi juga dimainkan Gus Mus. Pemilihan diksi menunjukkan representasi tertentu. Selanjutnya, permainan rima dan irama juga menjadi aspek penting pada puisi Gus Mus. Dalam sistem sosialbudaya, pada puisi Gus Mus fokus membahas urusan keyakinan yang menjadi identitas pada banyak puisinya. Dia menyindir cara berkeyakinan banyak umat Islam terutama di Indonesia yang mengabaikan esensi dan cenderung lebih menunjukkan citra saja. Selain itu, unsur sosio-budaya yang muncul adalah sentimen yang bisa parameter stabilitas sosial, dan tujuan yang menjadi arah pergerakan masyarakat. Tidak ketinggalan adalah kekuasaan yang penentu dan dominasi pada masyarakat, dan ketegangan juga bermain dengan penuturan yang paradoks.
\end{abstract}

Kata kunci: komunikasi sastra, puisi, sistem bahasa, sistem sosio-budaya

\section{LITERARY COMMUNICATION ON POEM SELAMAT TAHUN BARU KAWAN BY MUSTOFA BISRI}

\begin{abstract}
The purpose of this study was to explore literary to provide an understanding of communication in the poem Selamat Tahun Baru Kawan by KH Mustofa Bisri (Gus Mus) with a focus on dismantling the language system and sociocultural system. The approach of this study is qualitative and uses the content analysis method. Data collection techniques use documentation techniques. The data analysis technique starts from compiling a summary of the abstraction in the form of a body, explanation, and structuring. The results of this study indicate that language system in the poem by Gus Mus raises meaning that can be drawn in terms of denotative and connotative. Then, the diction game was also played by Gus Mus. Selection of diction shows a certain representation. Furthermore, rhyme and rhythm games are also important aspects of Gus Mus's poetry. In the socio-cultural system, in Gus Mus's poem the focus is on matters of faith which become identities in many of his poems. He insinuated the way to believe that many Muslims, especially in Indonesia,
\end{abstract}


ignored the essence and tended to show more image. In addition, the socio-cultural elements that emerge are sentiments that can be parameters of social stability, and goals that are the direction of community movement. Not to be left behind is decisive power and dominance in society, and tension also plays with paradoxical narrative.

Keywords: literature communication, poetry, language systems, sociocultural systems

\section{A. Pendahuluan}

Puisi merupakan bentuk komunikasi antara penyair dengan pembaca jika dalam bentuk tulis. Puisi juga bentuk komunikasi antara penyair dan pendengar jika puisi tersebut dibacakan. Itu bisa disebutkan sebagai komunikasi sastra karena puisi merupakan salah satu bentuk karya sastra yang dapat dikaji dari bermacam-macam aspeknya sesuai dengan jenisnya (Pradopo, 2009:3).

Disebut komunikasi sastra karena ada dua pihak yang berkomunikasi di mana penyair yang menyampaikan pesan melalui dan pembaca atau pendengar menerimanya dan bisa memberikan umpan balik. Berbeda dengan komunikasi pada umumnya, komunikasi dalam bingkai puisi mengandung nilai estetika dan makna yang dalam. Itu dikarenakan puisi bisa menjadi representasi budaya dan sosial sehingga memiliki banyak nilai dan manfaat.

Dengan begitu, dalam komunikasi sastra, puisi bukan hanya sekadar pesan yang ditransmisikan. Lebih dari itu, pesan yang disampaikan di dalam puisi bersifat abadi dan tidak akan mati ditelan zaman. Puisi juga universal karena bisa disebarkan tanpa batas ruang dan waktu. Siapapun bisa yang menikmati puisi kapanpun dan di manapun.

Nama KH. Mustofa Bisri bukan nama baru. Namanya sudah melanglang buana. Karyanya diakui karena sarat kritik sosial dan budaya. Puisinya selalu tampil beda dan telah memiliki genre sendiri. Banyak penyair mencoba meniru gaya berpuisi Gus Mus, panggilan akrab KH Mustofa Bisri. Akan tetapi, itu tidak berhasil. Orisinalitas Gus Mus dan puisinya memang diakui banyak pihak. Gaya puisi Gus Mus tak ada yang mampu meniru.

Kepopuleran Gus Mus dalam dunia sastra dikarenakan karyanya kerap diasosiasikan dengan Islam. Puisi yang ditulis Gus Mus selalu mengungkit fenomena umat di masyarakat. Dia mengangkat topik yang hangat. Bukan sekadar kritik, tapi bersifat reflektif. Salah satu puisi Gus Mus yang paling populer 
adalah Selamat Tahun Baru Kawan. Puisi tersebut biasanya viral setiap tahun baru Masehi atau Hijriyah di media sosial. Puisi tersebut juga tak pernah membosankan untuk dibaca berulang kali. Apalagi dibaca dan direnungkan saat perayaan malam tahun baru.

Pada dasarnya, komunikasi merupakan aktivitas yang dilakukan setiap hari oleh manusia. Tanpa komunikasi, tidak ada kehidupan di dunia. Itulah mengapa manusia selalu melakukan komunikasi. Rosengren (2006:1) mengungkapkan komunikasi mungkin terjadi antara unit yang memiliki ukuran dan kompleksitas yang berbeda. Komunikasi juga terjadi di antara individu, kelompok, organisasi, kelas sosial, bangsa, negara, dan kawasan di dunia. Di dalam komunikasi, terdapat ruang dan waktu yang sangat penting. Holmes (2005:6) menjelaskan komunikasi juga sebagai ritual tentang perubahan paradigma radikal dari pandangan status transmisi komunikasi.

Selanjutnya, menurut Holmes (2005:17), pola komunikasi juga berkembang bukan hanya berintegrasi karena adanya hierarki pada publik, institusional atau virtual. Namun, komunikasi tetap mengacu pada tatap muka, meskipun medium berbeda, seperti telepon dan internet. Steinberg (2007:44-50) mengungkapkan tentang komponen proses komunikasi. Pertama adalah orang sebagai komunikator, dan penerima pesan. Kedua adalah pesan sebagai konten yang disampaikan dalam komunikasi. Ketiga, tanda dan kode. Tanda adalah sesuatu berupa sesuatu atau ide. Sedangkan kode adalah sistem untuk penggunaan tanda berdasarkan aturan dan konvensi.

Keempat yakni encode dan decode. Encode adalah proses untuk mengambil ide dalam pikiran dan mentransformasikan dalam tanda verbal dan nonverbal sehingga mereka bisa ditransmisikan sebagai pesan kepada orang lain. Decode adalah proses untuk mengambil pesan verbal dan nonverbal yang bisa diterima dari orang lain dan memberikan makna. Kelima yakni, medium dan kanal. Medium yakni jalur fisik di mana pesan ditransfirmiasi antar orang dalam komunikasi, misalnya, telepon, koran, dan buku. Sedangkan kanal adalah rute yang dilakui pesan, misalnya suara. Keenam adalah umpan balik yakni berupa respons dari partisipan yang menjadi komunikasi tumbuh dinamis. Ketujuh yakni 
konteks yang mengacu pada lingkungan, tempat di mana komunikasi terjadi (Steinberg, 2007:44-50).

Dalam komunikasi, bukan hanya antar manusia. Akan tetapi, komunikasi juga berkembang dalam skala luas, seperti media massa termasuk juga buku dan novel. Karena pada dasarnya, semua bentuk komunikasi bisa dalam berbagai ruang dan bentuk. Apalagi, perkembangan teknologi memudahkan proses komunikasi dalam kehidupan manusia. Bersinggungan dengan sastra, bisa dikatakan sastra adalah representasi kehidupan. Kehidupan tidak akan berwarna tanpa sastra. Sastra juga mewarnai kehidupan. Keduanya tidak bisa dilepaskan satu sama lain karena sastra adalah bagian kehidupan.

Eagleton (2008:2) mengungkapkan sastra didefinisiikan bukan berdasarkan hal tersebut sebagai fisik atau imajinasi, tetapi bagaimana itu menggunakan bahasa yang khusus. Culler (2007:33) memaparkan karya sastra lebih dari sekar anekdot atau sesuatu yang menawarkan sesuatu yang detail. Representasi sastra memiliki otonomi yang luas sehingga bersifat universal. Struktur karya sastra juga bisa menceritakan kondisi manusia secara umum hingga spesifik (Culler, 2007:33).

Eagleton (2008:176) memaparkan kalau kritik sastra tidak bisa dijustifikasi sebagai pembatasan diri terhadap karya tertentu untuk mendapatkan nilai. Kritik sastra tidak berarti menjadi opini untuk menunjukkan suatu karya sastra itu hebat. Salah satu bentuk sastra adalah puisi. Selama ini, puisi dianggap sebagai bentuk ekspresi jiwa manusia. Namun, lebih dari itu, puisi juga sebagai bentuk representasi sosial yang menunjukkan realitas yang ada di masyarakat.

Pada dasarnya, sastra dan komunikasi merupakan dua hal yang saling berkaitan. Di dalam sastra terdapat unsur komunikasi karena ada pesan, dialog, dan orang yang terlibat. Sell (2000:29-31) menjelaskan karya sastra adalah salah bentuk tindak komunikasi yang mengandung sentuhan interpersonal. Sastra, seperti bentuk komunikasi lainnya, juga melintasi ruang dan waktu, yang mana juga melibatkan individu baik langsung atau tidak langsung. Akan tetapi, karya sastra seperti halnya puisi harus diciptakan dari kegiatan kreatif dan inovatif dalam betuk tulisan atau tercetak yang memiliki nilai keindahan dan tentunya 
tidak dapat dipisahkan dengan pengajaran bahasa oleh karena keduanya saling melengkapi, terutama sekali dalam pembelajaran bahasa yang selalu menggunakan karya sastra sebagai objek utamanya dalam menjelaskan dari ciri dan fungsi bahasa tersebut (Noermanzah, 2017:28).

Hasil penelitian relevan tentang kajian puisi karya Mustofa Bisri yaitu dilakukan oleh Firmansyah (2012:181) tentang pemikiran politik Islam dalam puisi K.H. Mustofa Bisri, sekaligus mengetahui penggunaan pendekatan hermenutik kerohanian dalam mengkaji puisi. Hasil penelitian ini menunjukkan bahwa unsur politik Islam sangat kental dalam kumpulan puisinya. Dengan demikian, dalam upaya politik untuk memperoleh dan mempertahankan kekuasaan yang ditampilkan dalam kumpulan puisinya selalu berpedoman pada ajaran Islam yang senantiasa telah melekat dalam dirinya. Pandangan dan kritik Mustofa Bisri melalui puisi-puisinya selalu berlandaskan pada moral politik Islam yang mengutamakan akhlak yang baik. Dari hasil penelitian relevan ini menunjukan bahwa belum pernah dilakukannnya penelitian tentang komunikasi sastra pada puisi Selamat Tahun Baru Kawan karya KH Mustofa Bisri (Gus Mus) dengan fokus membongkar sistem bahasa dan sistem sosio-budaya.

\section{B. Metode Penelitian}

Pendekatan yang diterapkan dalam penelitian ini adalah kualitatif. Metode penelitian yang digunakan penelitian ini adalah metode analisis isi. Dipilihnya analisis isi karena penelitian ini lebih mengutamakan analisis teks. Analisis teks merupakan bagian dari analisis isi. Selanjutnya, Mayring (dalam Titscher et al. (2009:22-25) menjelaskan mengenai prosedur analisis isi yang terdiri dari beberapa hal sebagai berikut: (1) ringkasan mencoba mengurangi materi sedemikian rupa sehingga bisa mengabadikan sisi pokoknya dan dengan melakukan abstraksi mencoba menciptakan suatu korpus yang bisa dikelola dan masih bisa mencerminkan materi aslinya. Untuk itu, teks (a) diparafrasakan, (b) digeneralisasikan atau diabstraksikan, dan (c) dikurangi. (2) Eksplikasi melibatkan kegiatan penjelasan, pengklarifikasian, dan penganotasian materinya. (3) Penataan struktur kurang lebih berkaitan dengan prosedur-prosedur yang digunakan dalam analisis konteks klasik juga dipandang sebagai teknik analisis isi 
yang paling penting, karena tujuannya adalah menyaring struktur tertentu dari materi yang dikaji.

Teknik pengumpulan data dalam penelitian ini yaitu teknik dokumentasi yang bersumber dari novel puisi karya Gus Mus berjudul Selamat Tahun Baru Kawan. Instrumen utama dalam penelitian ini adalah peneliti dengan uji keabsahan data dengan meningkatkan ketekunan dan penyajian data secara sistematis dalam bentuk tabulasi data hasil interpretasi data.

\section{Hasil Penelitian dan Pembahasan}

\section{Hasil Penelitian}

Penulis akan menganalisis puisi berjudul Selamat Tahun Baru Kawan karya Ahmad Mustafa Bisri dari perspektif komunikasi sastra yang fokus pada sistem bahasa dan sistem sosio-budaya. Puisi berjudul Selamat Tahun Baru Kawan merupakan bentuk komunikasi sastra antara Gus Mus dengan pembacanya. Di dalam komunikasi sastra dua hal yakni sistem bahasa dan sistem sosio-budaya. Hal itu dikarenakan komunikasi memang melibatkan bahasa sebagai simbol dan melibatkan konteks yakni sosial dan budaya yang berada di antara proses komunikasi tersebut.

Pada tahapan sistem bahasa, makna yang dimunculkan bisa ditarik dari segi denotatif dan konotatif. Kemudian, permainan diksi juga dimainkan Gus Mus. Pemilihan diksi menunjukkan representasi tertentu. Selanjutnya, permainan rima dan irama juga menjadi aspek penting pada puisi Gus Mus. Selanjutnya, dalam sistem sosial-budaya, pada puisi Gus Mus fokus membahas urusan keyakinan yang menjadi identitas pada banyak puisinya. Dia menyindir cara berkeyakinan banyak umat Islam terutama di Indonesia yang mengabaikan esensi dan cenderung lebih menunjukkan citra saja. Selain itu, unsur sosialbudaya yang muncul adalah sentimen yang bisa parameter stabilitas sosial, dan tujuan yang menjadi arah pergerakan masyarakat. Tidak ketinggalan adalah kekuasaan yang penentu dan dominasi pada masyarakat, dan ketegangan juga bermain dengan penuturan yang bersifat paradoks. 
Puisi yang akan dianalisis berjudul Selamat Tahun Baru Kawan. Puisi tersebut merupakan salah satu dari buku Antologi Puisi Tadarus karya Gus Mus, yang diterbitkan oleh Adicita Karya Nusa Yogyakarta pada 2003. Berikut puisi Selamat Tahun Baru Kawan karya Mustofa Bisri (2003).

\author{
Selamat Tahun Baru Kawan \\ Kawan, sudah tahun baru lagi \\ Belum juga tibakah saatnya kita menunduk memandang diri sendiri \\ Bercermin firman Tuhan, sebelum kita dihisab-Nya
}

Kawan siapakah kita ini sebenarnya?

Muslimkah, mukminin, muttaqin,

kholifah Allah, umat Muhammadkah kita?

Khoirul ummatinkah kita?
Atau kita sama saja dengan makhluk lain atau bahkan lebih rendah lagi
Hanya budak perut dan kelamin
Iman kita kepada Allah dan yang ghaib rasanya lebih tipis dari uang kertas ribuan
Lebih pipih dari kain rok perempuan
Betapapun tersiksa, kita khusyuk didepan masa
Dan tiba tiba buas dan binal disaat sendiri bersama-Nya
Syahadat kita rasanya lebih buruk dari bunyi bedug,atau pernyataan setia pegawai rendahan saja.
Kosong tak berdaya.

Shalat kita rasanya lebih buruk dari senam ibu-ibu

Lebih cepat dari pada menghirup kopi panas dan lebih ramai daripada lamunan 1000 anak pemuda.

Doa kita sesudahnya justru lebih serius memohon enak hidup di dunia dan bahagia dis urga. Puasa kita rasanya sekadar mengubah jadual makan minum dan saat istirahat, tanpa menggeser acara buat syahwat, ketika datang rasa lapar atau haus.

Kita manggut manggut, ooh...beginikah rasanya dan kita sudah merasa memikirkan saudara saudara kita yang melarat.

Zakat kita jauh lebih berat terasa dibanding tukang becak melepas penghasilanya untuk kupon undian yang sia-sia

Kalaupun terkeluarkan, harapan pun tanpa ukuran upaya-upaya Tuhan menggantinya lipat ganda

Haji kita tak ubahnya tamasya menghibur diri, mencari pengalaman spiritual dan material, membuang uang kecil dan dosa besar.

Lalu pulang membawa label suci asli made in saudi "HAJI"

Kawan, lalu bagaimana dan seberapa lama kita bersama-Nya atau kita justru sibuk menjalankan tugas mengatur bumi seisinya, mensiasati dunia khalifahnya,

Kawan, tak terasa kita semakin pintar, mungkin kedudukan kita sebagai khalifah mempercepat proses kematangan kita paling tidak kita semakin pintar berdalih

Kita perkosa alam dan lingkungan demi ilmu pengetahuan

Kita berkelahi demi menegakkan kebenaran,mengacau dan menipu demi keselamatan

Memukul, mencaci demi pendidikan

Berbuat semaunya demi kemerdekaan

Tidak berbuat apa apa demi ketenteraman

Silampari Bisa: Jurnal Penelitian Pendidikan Bahasa Indonesia, Daerah, dan Asing Vol. 1, No. 2, 2018 
Membiarkan kemungkaran demi kedamaian pendek kata demi semua yang baik halallah sampai yang tidak baik.

Lalu bagaimana para cendekiawan, seniman, mubaligh dan kiai sebagai penyambung lidah Nabi

Jangan ganggu mereka

Para cendekiawan sedang memikirkan segalanya

Para seniman sedang merenungkan apa saja

Para mubaligh sedang sibuk berteriak kemana-mana

Para kiai sibuk berfatwa dan berdoa

Para pemimpin sedang mengatur semuanya

Biarkan mereka di atas sana

Menikmati dan meratapi nasib dan persoalan mereka sendiri

(KH Ahmad Mustofa Bisri, 2003)

\section{Pembahasan}

Penulis menganalisis puisi berjudul Selamat Tahun Baru Kawan dengan menggunakan metode analisis. Krippendorf (2004:3) menyebutkan analisis isi merupakan proses pembacaan terhadap tubuh teks, gambar, dan hal simbolik, tanpa perlu membutuhkan perspektif penulis atau pengguna. Analisis isi pada puisi ini berdasarkan teori tentang komunikasi sastra. Seperti diungkapkan, Claassen (2012:47-48), komunikasi sastra memiliki tiga elemen dasar yakni penulis, teks, dan pembaca, biasanya akan terlibat dalam situasi komunikasi yang spesifik. Dari ketiga elemen tersebut, komunikasi sastra bisa dijabarkan tentang proses teks sastra (Claassen, 2012:47).

Panduan referensi utama penelitian adalah pendapat Siswanto (2008:21) yang menyebutkan tentang komunikasi menjelaskan dalam komunikasi sastra, selain memperhatikan sistem bahasa, sastrawan juga masih harus memperhatikan sistem sosio-budaya. Meskipun kreativitas dijunjung tinggi dan meskipun sastrawan mempunyai licentia poetica, sastrawan tetap harus memerhatikan sistem sosio-budaya masyarakat pembacanya. Licentia poetica adalah kebebasan pengarang untuk menyimpang dari kenyataan, dari bentuk atau aturan, untuk mencapai suatu efek.

\section{a. Sistem Bahasa sebagai Bagian dari Komunikasi Sastra}

Dalam komunikasi sastra, sistem bahasa didefinisikan. Aminudin (1987:93) mengungkapkan, dari segi komunikasi, bahasa sastra memiliki ciri-ciri: (1) polisemantis dan multifungsional, (2) wujud sistem dari sistem, karena bahasa 
sastra dilandasi sistem bahasa natural dan sistem kode dalam konvensi sastra, (3) dalam kadar tertentu, khususnya puisi menunjukkan pemadatan struktur kebahasaan, pengayaan makna, variasi pola struktur, dan (4) mengandung konotasi makna yang bersifat individual.

Menurut Aminudin (dalam Warsiman, 2017:111) mengungkapkan bahasa dalam komunikasi sastra juga bersifat polisemantis. Hal itu terjadi karena makna dalam bahasa sastra berkaitan dengan: (1) makna yang secara konvensional terkandung dalam bahasa itu sendiri; (2) makna sehubungan dengan dunia luar bahasa, baik berkaitan dengan fakta kehidupan maupun latar sosial-budaya; (3) makna yang ditimbulkan oleh hubungan konteks tekstualnya; dan (4) makna yang berhubungan dengan referensi maupun konseptual hanyalah penafsirannya.

Dalam sudut pandang komunikasi sastra, bahasa selalu bersifat polisemantis. Hal tersebut mengacu kalau tidak ada bahasa yang memiliki makna tunggal. Bahasa selalu menimbulkan tafsir yang beragam dan kompleks. Apalagi dalam bahasa puisi yang selalu menimbulkan makna ganda yang bisa saja antar penafsir satu dengan pembaca lainnya akan memiliki makna yang berbeda dalam memandang suatu kata. Seperti diungkapkan Hanauer (2014), bahwa puisi bisa menunjukkan ekspresi afektif yang bisa menimbulkan komunikasi afeksi dan rekognisi akurasi sehingga menghasilkan ekspresi afektif (Zajonc, 1980) dan ekspansi linguistik yang memiliki linguistik yang menakjubkan dan bersifat polisemantik, terkadang imajinistik dan berdasarkan narasi, serta otobiografi serta estetik.

Selamat Tahun Baru Kawan sebagai judul puisi yang ditulis Gus Mus juga memiliki nama yang beragam. Ucapan selamat tahun baru secara umum bersifat kebahagiaan dan memberikan harapan baru bagi orang yang diberi ucapan selamat. Namun, setelah membaca keseluruhan puisi tersebut, justru tidak ada ucapan bersifat selamat yang mengandung kesenangan. Gus Mus justru menghadirkan Selamat Tahun Baru lebih bersifat relektif.

Puisi itu seperti ditujukan untuk mengajak semua orang untuk melihat diri mereka sendiri. Gus Mus menyebut mereka sebagai "kawan". Hal tersebut menunjukkan adanya kesetaraan di antara Gus Mus dengan pihak-pihak yang disebutkan dalam puisi tersebut. Dia tidak memosisikan dirinya lebih tinggi atau 
pun lebih rendah. Dia ingin berada pada tingkatan yang setara dengan orang yang ingin diingatkan dan diajak merenungi makna tahun baru.

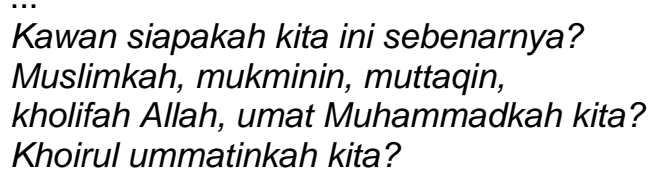

(Bisri, 2003)

Pada bait puisi di atas menunjukkan adanya penandaan struktur kebahagiaan, pengayaan makna, variasi pola struktur seperti diungkapkan Aminudin (1987). Muslim, mukminin, dan muttaqin merupakan steorotipe dalam kepribadian seorang penganut agama Islam. Muslim adalah tingkatan dasar yakni orang yang pernah mengucapkan kalimat syahadat. Kalau mukminin adalah orang beriman dan muttaqin adalah orang yang bertakwa yang mana melaksanakan perintah dan larangan Allah. Bukan hanya itu, kholifah Allah adalah manusia sebagai pemimpin di dunia. Steoretipe yang sangat menyindir adalah umat Nabi Muhammad. Khoirul ummatin adalah umat yang baik.

Klasifikasi itu menunjukkan tingkatan berdasarkan ketaatan seorang. Hal tersebut merupakan bentuk variasi struktur yang dimainkan Gus Mus dalam puisinya. Bukan hanya makna denotatif yang muncul pada diksi tersebut, tetapi juga muncul makna konotatif di dalamnya. Tingkatan paling rendah adalah orang Muslim dan level paling tinggi yakni khoirul ummatin. Hal tersebut menunjukkan target Selamat Tahun Baru Kawan adalah orang yang seakidah dengan Gus Mus, yakni orang Islam dari tingkatan paling rendah hingga paling tinggi.

Bukan hanya makna denotatif yang muncul pada diksi tersebut. Akan tetapi, juga muncul makna konotatif di dalamnya. Muslim merupakan kelompok yang pertama disebut Gus Mus, tetapi bukan mereka sebagai target utama yang disindir. Namun, khoirul ummatin merupakan kelompok yang paling menjadi target utama. Permainan itu juga ditunjukkan dengan bagaimana steoritipe itu juga berlanjut pada tataran yang ada di masyarakat. Hal tersebut dikarenakan seorang Islam memiliki peran di masyarakat. 
Lalu bagaimana para cendekiawan, seniman, mubaligh dan kiai sebagai penyambung lidah Nabi Jangan ganggu mereka

$\cdots$

(Bisri, 2003)

Dari kutipan puisi di atas, menunjukkan bahwa pemilihan diksi tersebut tentunya bagaimana kategorisasi dalam orang Islam itu termanifestasikan dalam berbagai profesi yang memiliki peran di masyarakat. Mereka yang disebut Gus Mus dalam puisinya menunjukkan adanya kontribusi besar mereka bagi masyarakat. Cendekiawan, bukan hanya representasi orang yang memiliki ilmu. Tapi, cendekiawan merupakan representasi kelompok orang yang tidak lagi memanfaatkan ilmunya untuk masyarakat. Keilmuan mereka hanya menjadi "menara gading" yang bermanfaatkan bagi diri mereka dan kelompok mereka, bukan untuk kemaslahatan umat.

Seniman, bukan hanya representasi orang yang berkiprah untuk menghasilkan karya seni. Seniman, bukan lagi orang yang mampu menghibur dan menciptakan kesenangan di masyarakat. Karya seni merek hanya dikonsumsi diri mereka sendiri dan kelompok mereka, tidak bisa dinikmati masyarakat. Dalam kajian sistem bahasa, permainan rima dan irama juga dimainkan dalam puisi tersebut. Meskipun hal itu tidak menjadi dominan dalam puisi tersebut. Hal itu hanya sebagai selingan untuk menghadirkan estetika sehingga enak dibaca dan nyaman ketika didengarkan.

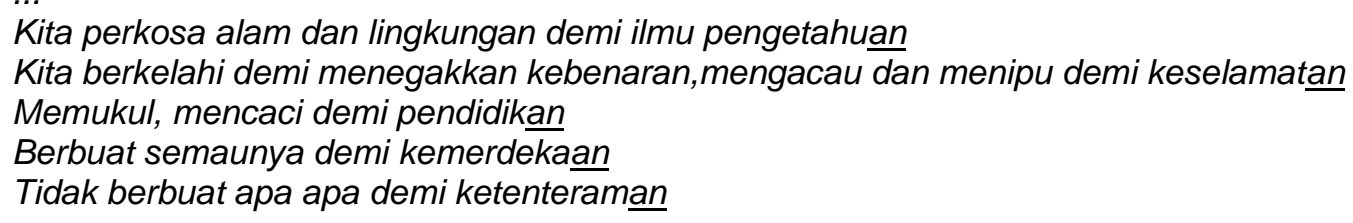

(Bisri, 2013)

Dari kutiapn puisti di atas, menunjukkan bahasa puisi merupakan bahasa yang unik. Salah satunya adalah penekanan pada rima dan irama saja yang dimainkan. Memang rima dan irama akan menimbulkan kesan yang berbeda ketika puisi tersebut dibaca. Rima dan irama juga bisa menjadi suatu bentuk penegasan kalau karya tersebut adalah puisi. Pasalnya, rima dan irama memang 
sudah menjadi hal yang identik dengan puisi. Meskipun, banyak juga penyair yang menyusun puisi tanpa memperhatikan irama dan rima.

Dalam pandangan penulis, justru puisi yang memiliki irama dan rima akan memiliki daya kekuatan yang lebih meledak ketika dibaca dibandingkan puisi yang tidak memilikinya. Bukan saja pendengar saja akan menikmati, tetapi seorang penyair yang membacakan puisi akan merasakan getaran dari efek rima dan irama. Getaran itu sendiri akan menimbulkan semangat dan menumbuhkan atmosfir yang sesuai dengan isi puisi tersebut.

Rima dan irama dalam puisi Gus Mus itu juga menunjukkan kecerdasan penyair yang menulisnya. Itu tidak hanya berkaitan dengan pemilihan diksi dengan akhiran yang sama. Jauh dari itu. Di sana ada proses perenungan yang mendalam. Termasuk di dalamnya ada makna yang saling berkaitan satu sama lain.

\section{b. Sistem Sosio-budaya dalam Komunikasi Sastra}

Dalam menganalisis sosial-budaya mengacu pada teori yang dikemukakan Bertrand (1980), tentang unsur sistem sosial budaya yang bisa menjadi panduan. Unsur sistem sosial tersebut adalah keyakinan, perasaan, tujuan, norma, status, tingkatan, kekuasaan, sanksi, sarana, dan ketegangan (Bertrand, 1980). Mengenai sistem sosial budaya, Hess-Luttich (1985:199) menjelaskan komunikasi sastra lebih banyak dikaitkan dengan struktur semiotik sosial, konteks sejarah, lokasi institusional, dan implikasi psikologis. Hess-Luttich (1985:199) mengungkapkan prinsip dasar komunikasi sastra mengacu pada model komunikasi sastra terdiri dari pengirim yakni penulis, penerima adalah pembaca, dan kanalnya adalah teks. Dalam analisis komunikasi sastra tidak hanya membedakan struktur dan fungsi wacana sehari-hari dan dialog fiksi, tetapi juga hubungan khusus antara penulis dan pembaca dengan konteks dan lokasi.

Schmidt (dalam Claassen (2012:47) mengungkapkan komunikasi sastra bisa dipandangan dari perspektif sosiologi yang mana ada keterkaitan antara produksi dan resepsi teks sastra di mana teks adalah objek komunikasi sastra. Menurut Hess-Luttich (dalam Warsiman, 2017:101) menjelaskan komunikasi sastra dalam 
sudut pandan sosial-budaya sangat berbeda dengan komunikasi dalam cakupan linguistik. Komunikasi sastra lebih ditekankan pada representasi estetika yang dilakukan penulis. Komunikasi sastra juga merupakan interaksi antara penulis dan pembacanya menggunakan sastra, bisa menggunakan panggung sebagai mediumnya.

Ewers (2009:10) menjelaskan bahwa dalam komunikasi sastra berhadapan dengan komunikasi tulis yang direpresentasikan situasi bicara yang diperluas. Ada dua elemen di dalanya yakni "situasi bicara" yakni produksi pesan oleh pembicara dan diterima pendengar, dan "situasi bicara yang tidak selesai" di mana itu tidak berkaitan dengan kontak personal (Ewers, 2009:10). Lebih detail, Ewers (2009:10) mengungkapkan bahwa komunikasi sastra berbeda dengan bentuk komunikasi yang lebih bersifat ilmiah atau komunikasi sehari-hari. Komunikasi sastra karena melibatkan teks fiksi, meskipun di sana ada faktor faktual dan informasional.

Siswanto (2008:87) mengungkapkan, dalam dunia sastra, ada juga komunikasi sastrawan dengan karya sastra. Komunikasi sastrawan dengan karya sastra bisa terdiri atas (1) komunikasi antara sastrawan dengan karya sastranya sendiri dan (2) komunikasi sastrawan dengan karya sastra orang lain. Komunikasi tersebut lebih bersifat fungsional, yakni manfaat karya sastra yang telah ditulisnya bagi sastrawan sendiri.

Penulis menyepakati dalam analisis komunikasi sastra melibatkan sistem bahasa dan sistem sosial budaya. Hal tersebut tidak lain karena kedua sistem tersebut memang melekat pada sastra dan komunikasi. Untuk mengkomunikasikan sistem bahasa dan sosial budaya, maka penyair atau penulis berkomunikasi dengan dirinya sendiri atau intrapersonal dan mengkomunikasikan dengan pembacanya atau interpersonal.

Sistem sosial yang sangat utama muncul dalam puisi Gus Mus adalah masalah keyakinan. Itu tidak lepas karena Gus Mus adalah seorang ulama Nahdatul Ulama yang sudah diakui kealimanannya dan keilmuannya banyak puisinya juga kerap bersinggungan dengan urusan keyakinan, yakni Islam. Keyakinan memang sebenarnya bukan hanya berkaitan dengan agama semata, tetapi, keyakinan, misalnya agama, memiliki nilai yang terukur dan bersifat komunal.

Silampari Bisa: Jurnal Penelitian Pendidikan Bahasa Indonesia, Daerah, dan Asing Vol. 1, No. 2, 2018 
Dalam puisinya, Gus Mus menyindir keras berkaitan dengan keyakinan. Dia juga mengkritik konsep keyakinan pada diri sebagian umat Islam yang dinilai tidak lagi sesuai dengan keyakinan yang sebenarnya. Dia ingin menggugah tentang arah kompas keyakinan pada diri manusia.

Shalat kita rasanya lebih buruk dari senam ibu-ibu

Lebih cepat dari pada menghirup kopi panas dan lebih ramai daripada lamunan 1000 anak pemuda.

(Bisri, 2003)

Sebuah sindiran yang sangat keras dari Gus Mus. Salat adalah amalan yang pertama dihisab di akhirat. Ukuran keimanan seorang Muslim umumnya dilihat dari salat. Apalagi, salat juga disebut sebagai tiang agama. Ketika salat saja sudah disepelekan dan dinomorduakan, maka keyakinan pun bisa keropos dan mudah digoyang.

Sebagian umat Islam tidak lagi menjadikan salat sebagai urusan penting. Mereka lebih senang dengan urusan dunia yang fana dan sementara. Padahal, urusan keyakinan bukan urusan hati saja. Urusan keyakinan terutama salat juga menjadi pijakan untuk menjadi pribadi yang lebih baik

Perasaan sentimen juga menjadi bagian dari sistem sosial. Perasaan bukan urusan pribadi semata karena masyarakat adalah mahkluk sosial. Dia tidak bisa hidup sendirii. Keberlangsungan suatu masyarakat juga ditentukan oleh perasaan yang ada di dalam hati manusia, apakah rasa suka, benci, dan lain sebagainya.

Memukul, mencaci demi pendidikan $\ldots$

(Bisri, 2003)

Dari kutipan di atas, terdapat makna perasaan menentukan stabilitas sosial di masyarakat. Gus Mus mengingatkan semua orang kebencian akan mengakibatkan penderitaan. Cacian tidak akan mewujudkan harapan. Perkelahian tidak akan mewujudkan keinginan. Meskipun kebencian, cacian, dan perkelahian itu untuk mencapai tujuan baik bagi mereka seperti pendidikan. Seolah-olah Gus Mus ingin mengajak kembali umat Islam untuk berpegang teguh kembali kembali Silampari Bisa: Jurnal Penelitian Pendidikan Bahasa Indonesia, Daerah, dan Asing Vol. 1, No. 2, 2018 
untuk menggunakan perasaan untuk hal hal kebaikan. Perasaan harus diisi dengan kasih dan sayang, cinta dan kepedulian, menjaga dan mengingatkan. Jangan korban perasaan untuk hal yang merusak hati yang berujung mengganggu relasi sosial.

Selanjutnya, tujuan menjadi hal penting dalam sistem sosial. Tujuan bisa diwujudkan dalam cita cita seseorang dan cita cita masyarakat. Hal tersebut yang akan mengendalikan perasaan dan pikiran untuk kehidupan sosial yang lebih baik.

Doa kita sesudahnya justru lebih serius memohon enak hidup di dunia dan bahagia di surga.

(Bisri, 2003)

Dari kutipan puisi di atas, doa merupakan awalan pertama dalam mewujudkan target. Melalui doa, manusia akan memiliki target yang jelas. Melalui doa, orang juga akan melihat visi dan misi yang lebih jelas untuk mewujudkan citacita. Dengan doa, semangat pun bisa dipupuk sehingga langkah dan ayunan akan semakin mantap. Akan tetapi, justru cita-cita manusia hanya menginginkan kenikmatan dunia dan di surga. Mereka lebih peduli dengan hal yang menyenangkan dan membahagiakan saja. Bahkan, hanya untuk diri mereka sendiri, kelompok mereka, dan golongan mereka.

Mereka melupakan hal yang penting. Kemaslahatan umat manusia. Mereka mengabaikan persatuan dan kesatuan bangsa. Mereka lupa bahwa banyak masyarakat lain juga harus diperjuangkan dan dibantu. Cita-cita sebenarnya bukan hanya untuk diri sendiri, tetapi juga untuk bisa bermanfaat untuk orang lain.

Selanjutnya, kekuasaan menjadi sistem sosial yang sangat lekat dengan unsur politik. Mereka yang berkuasa dalam iklim demokrasi dipilih oleh rakyat. Meski terkadang menghalalkan segala cara untuk mendapatkan kursi. Meski kekuasaan diraih dengan kezaliman. Hal tersebut terjadi karena kekuasaan menjadi magnet yang mampu memperkuat diri dan kelompoknya.

Para pemimpin sedang mengatur semuanya

Biarkan mereka di atas sana

Menikmati dan meratapi nasib dan persoalan mereka sendiri

(Bisri, 2003)

Silampari Bisa: Jurnal Penelitian Pendidikan Bahasa Indonesia, Daerah, dan Asing Vol. 1, No. 2, 2018 
Sebagai sistem sosial yang memiliki kekuatan, kekuasaan dalam hal ini adalah pemerintah mampu mendominasi kehidupan sosial. Mereka hadir karena mereka memiliki alat kekuasaan untuk menegakkan hukum dan aturan. Namun, kekuasaan juga memiliki tanggung jawab besar karena harus bertanggungjawab dalam hal keamanan dan kesejahteraan rakyat yang dipimpinnya. Mereka tidak bisa semena-mena karena mereka terikat dengan janji politik. Akan tetapi, seperti yang disindir Gus Mus, kekuasaan yang dipegang oleh pemimpin justru menghadapi dilema. Mereka menikmati dan meratapi. Gus Mus sepertinya ingin menggugah semua pemimpin yang terlalu sibuk mengurusi urusan sendiri, tetapi mengabaikan urusan yang lebih penting yakni rakyatnya. Dia juga mengajak masyarakat untuk tak perlu meributkan para pemimpin yang sibuk dengan urusannya sendiri.

Kemudian, ketegangan sangat bermain pada puisi Gus Mus. Dia menampilkan dua sisi yang berbeda dan bersifat paradoks. Itu menjadi fenomena kebanyakan orang di Indonesia. Hal itu sangat serius karena tidak ada manusia tidak lagi percaya dengan esensi, karena citra bisa yang ditampilkan bisa menipu. Sikap dan pemikiran tidak mencerminkan pemikiran dan perasaan. Hal tersebut dikarenakan banyak manusia mengandalkan rekayasa dalam kehidupan mereka. Kawan, tak terasa kita semakin pintar, mungkin kedudukan kita sebagai khalifah
mempercepat proses kematangan kita paling tidak kita semakin pintar berdalih
Kita perkosa alam dan lingkungan demi ilmu pengetahuan
Kita berkelahi demi menegakkan kebenaran, mengacau dan menipu demi keselamatan
Memukul, mencaci demi pendidikan
Berbuat semaunya demi kemerdekaan
Tidak berbuat apa apa demi ketenteraman
Membiarkan kemungkaran demi kedamaian pendek kata demi semua yang baik halallah
sampai yang tidak baik.

(Bisri, 2003)

Dari kutipan puisi di atas, mengandung makna bahwa manusia zaman sekarang memang suka berdalih. Terkadang mereka mengetahui apa yang mereka lakukan itu salah, tetapi mereka menggunakan pengetahuan untuk mencari dalih, mencari pembenaran dengan kebutuhan masyarakat, dan mengusaha semuanya berjalan lancar dengan segala cara. Tipuan demi 
kepentingan pribadi pun menjadi hal biasa. Dengan dalih untuk kebutuhan dan kepentingan masyarakat.

Gus Mus mengkritik sebagian masyarakat yang selalu melihat segala sesuatu dari jangka pendek, bukan jangka panjang. Otak mereka lebih berpikir pendek, enggan berpikir panjang. Hal tersebut karena mereka terjebak pemikiran dan konsep yang salah tentang hidup. Gus Mus menjelaskan kalau itu semua karena orang belum mengalami "proses pematangan" yang cukup dalam keilmuan dan keprofesionalitasan. Mereka mudah dibeli oleh uang, kekuasaan, dan pengalaman. Mereka tidak mau berpijak pada moralitas dan kepentingan bersama.

\section{Simpulan}

Puisi berjudul Selamat Tahun Baru Kawan merupakan bentuk komunikasi sastra antara Gus Mus dengan pembacanya. Sistem bahasa pada puisi karya Gus Mus tersebut memunculkan makna yang bisa ditarik dari segi denotatif dan konotatif. Kemudian, permainan diksi juga dimainkan Gus Mus. Pemilihan diksi menunjukkan representasi tertentu. Selanjutnya, permainan rima dan irama juga menjadi aspek penting pada puisi Gus Mus.

Dalam sistem sosial-budaya, pada puisi Gus Mus fokus membahas urusan keyakinan yang menjadi identitas pada banyak puisinya. Dia menyindir cara berkeyakinan banyak umat Islam terutama di Indonesia yang mengabaikan esensi dan cenderung lebih menunjukkan citra saja. Selain itu, unsur sosial-budaya yang muncul adalah sentimen sebagai parameter stabilitas sosial dan tujuan yang menjadi arah pergerakan masyarakat. Tidak ketinggalan adalah kekuasaan yang menentukan dan dominasi pada masyarakat, serta ketegangan juga bermain dengan penuturan yang paradoks. 


\section{Daftar Pustaka}

Aminudin. (1987). Pengantar Apresiasi Karya Sastra. Malang: Sinar Baru.

Bertrand, Alvin L. (1980). Sosiologi. Penerjemah: Sanafiah S. Faisal. Surabaya: Bina Ilmu.

Bisri, Ahmad Mustofa. (2003). Tadarus: Antologi Puisi. Yogyakarta: Adicita Karya Nusa.

Claasen, Eefje. (2012). Author Representations in Literary Reading. Amsterdam: John Benjamins Publishing Company.

Culler, Jonathan D. (2007). The Literary in Theory. Stanford: Standford University Press.

Eagleton, Terry. (2011). Literary Theory: An Introduction. Blackwell Publishing.

Ewers, Hans-Heino. (2009). Fundamental Concepts of Children's Literature Research: Literary and Sociological Approaches. New York: Routledge.

Firmansyah, Erfi. (2012). Pemikiran Politik Islam Mustofa Bisri dalam Puisi: Persfektif Hermeneutika Kerohanian. Literasi, 2(2), 181-197.

Hanauer, D. I. (2014). "Appreciating the Beauty of Second Language poetry Writing". Dalam Disney, Dan. 2014. Exploring Second Language Creative Writing: Beyond Babel. Amsterdam: John Benjamin Publishing. Hal. 11-22.

Hess-Luttich, Ernest W B. (1985). Dramatic Discourse. Dalam Teun A. van Dijk (editor). "Discourse and Literature: New Approaches to the Analysis of Literary Genres". Amsterdam: John Benjamins Publishing Company.

Holmes, David. (2005). Communication Theory: Media, Technology and Society. London: Sage Publications.

Krippendorf, Klaus. (2004). Content Analysis: An Introduction to Its Methodology. London: Sage Publications.

Noermanzah, N. N. (2017). Plot in a Collection of Short Stories "Sakinah Bersamamu" Works of Asma Nadia with Feminimism Analysis. Humanus, 16(1), 27. doi:10.24036/jh.v16i1.7015

Pradopo, R. J. (2009). Pengkajian Puisi: Analisis Strata Norma dan Analisis Struktural dan Semiotik. Yogyakarta: Gadjah Mada University Press. 
Rosengren, Karl Erik. (2006). Communication: An Introduction. London: Sage Publications.

Sell, Roger D. (2000). Literature as Communication: The Foundations of Mediating Criticism. Amsterdam: John Benjamins Publishing Company.

Siswanto, Wahyudi. (2008). Pengantar Teori Sastra. Pengarang. Jakarta: Grasindo.

Steinberg, Sheila. (2007). An Introduction to Communication Studies. Cape Town: Juta \& Co Ltd.

Titscher, Stefan et al. (2009). Metode Analisis Teks dan Wacana. Terjemahan (Gozali dkk). Yogyakarta: Pustaka Pelajar.

Warsiman. (2017). Pengantar Pembelajaran Sastra: Sajian dan Kajian Hasil Riset. Malang: UB Press.

Zajonc, R. B. (1980). Feeling and Thinking: Preferences Need no Inferences. American Psychologist, 35(2), 151. 